Geosistemy perehodnykh zon = Geosystems of Transition Zones $/$ Геосистемы переходных зон

Content is available under the Creative Commons Attribution 4.0 International License (CC BY 4.0)

2020, vol. 4, No. 4, pp. 447-473

URL: http://journal.imgg.ru/archive.html ; https://elibrary.ru/title about.asp?id=64191

https://doi.org/10.30730/gtrz.2020.4.4.447-460.461-473

\title{
Short-term forecast of local tsunamis based on data containing seismic noise from deep-ocean stations closest to the sources
}

Yury P. Korolev*, Pavel Yu. Korolev

Institute of Marine Geology and Geophysics, FEB RAS, Yuzhno-Sakhalinsk, Russia

*E-mail: Yu_P_K@mail.ru

\section{Abstract PDF ENG Резюме PDF RUS $\quad$ Full text PDF RUS \& ENG}

Abstract. Reliable short-term tsunami forecast on the Kuril Islands when earthquakes occur in the Kuril-Kamchatka Trench is the most difficult. Forecasting by the traditional magnitude method often leads to false tsunami alarms. Based on the examples of the events of 2006, 2007 and 2020 on the Kuril Islands, as well as the event of 2018 in Alaska, it was shown that according to the data of the ocean level measuring stations closest to the tsunami source (tsunami travel time is 10-20 minutes) it is possible to adequately predict the tsunami near the coast. Calculations of tsunami waveforms near the coast from data containing seismic noise have shown that the resulting waveforms contain high-frequency oscillations. However, these fluctuations do not interfere with the assessment of the real waveform and the danger of the expected tsunami. In contrast to forecast methods based on the magnitude criterion, the applied method of short-term tsunami forecast makes it possible to calculate the waveform: the amplitudes of the first, maximum waves, their arrival time at a given point and the estimated duration of the tsunami. The proposed method can become a tool that will improve the quality of operational tsunami warning, significantly reducing the number of false tsunami alarms.

\section{Keywords:}

tsunami, earthquake magnitude, tsunami alarm, Onekotan, Kuril Islands, Severo-Kurilsk, method of short-term tsunami forecast, forecast lead time, DART, seismic noise

For citation: Korolev Yu.P., Korolev P.Yu. Short-term forecast of local tsunamis based on data containing seismic noise from deep-ocean stations closest to the sources. Geosistemy perehodnykh zon = Geosystems of Transition Zones, 2020, vol. 4, no. 4, pp. 393-446. (In Russ. \& Engl.). https://doi.org/10.30730/gtrz.2020.4.4.447-460.461-473

Для цитирования: Королев Ю.П., Королев П.Ю. Оперативный прогноз локальных цунами по данным ближайших к очагам глубоководных станций, содержащим шумы сейсмического происхождения. Геосистемы переходных зон, 2020, т. 4, № 4, с. 393-446. (На рус. и англ. яз.). https://doi.org/10.30730/gtrz.2020.4.4.447-460.461-473

\section{References}

1. Gusiakov V.K. 2011. Relationship of tsunami intensity to source earthquake magnitude as retrieved from historical data. Pure and Applied Geophysics, 168(11): 2033-2041. https://doi.org/10.1007/s00024-011-0286-2

2. Korolev Yu.P. 2011. An approximate method of short-term tsunami forecast and the hindcasting of some recent events. Natural Hazards and Earth System Sciences, 11: 3081-3091. https://doi:10.5194/nhess-11-3081-2011

3. Korolev Yu.P. 2019. On opportunity of short-term forecast for local tsunamis in the Kuril Islands. Fundamentalnaya $i$ Prikladnaya Gidrofizika [Fundamental and applied hydrophysics], 12(4): 14-20. (In Russ).

4. Lavrentiev M., Lysakov K., Marchuk An., Oblaukhov K., Shadrin M. 2019. Fast evaluation of tsunami waves heights around Kamchatka and Kuril Islands. Science of Tsunami Hazards, 38(1): 1-13.

5. Nurislamova G.N., Nosov M.A. 2016. The horizontal motion of a water layer during the passage of tsunami waves based on data from a dense ocean-floor network of deepwater sea-level stations. Moscow University Physics Bulletin, 71(5): 520-525. https://doi.org/10.3103/s0027134916050143

6. Titov V.V. 2009. Tsunami forecasting. In: E.N. Bernard, A.R. Robinson (eds). The Sea. Vol. 15: Tsunamis. Cambridge, MA; London, England: Harvard Univ. Press, 367-396.

7. Wei Y., Cheung K.F., Curtis G.D., McCreery Ch.S. 2003. Inverse algorithm for tsunami forecasts. J. Waterway, Ports, Coastal and Ocean Engineering. ASCE, 129(2): 60-69. https://doi.org/10.1061/(asce)0733-950x(2003)129:2(60)

8. Whitmore P.M., Sokolowski T.J. 1996. Predicting tsunami amplitudes along the North American coast from tsunamis generated in the Northwest Pacific Ocean during tsunami warnings. Science of Tsunami Hazards, 14(3): 147-166.

\section{Data sources}

1. National Centers for Environmental Information: Search Tsunami Events. URL:

https://www.ngdc.noaa.gov/hazel/view/hazards/tsunami/event-search (accessed 6.11.2020)

2. National Data Buoy Center. URL: https://ndbc.noaa.gov/dart.shtml (accessed 6.11.2020)

3. NOAA Center for Tsunami Research: DART. URL: http://nctr.pmel.noaa.gov/Dart (accessed 6.11.2020) 
4. NOAA Center for Tsunami Research: Kodiak, Alaska Tsunami, January 23, 2018 Main Event Page.

URL: https://nctr.pmel.noaa.gov/alaska20180123 (accessed 6.11.2020)

5. NOAA Center for Tsunami Research: Kuril Islands Tsunami, March 25, 2020 Main Event Page.

URL: https://nctr.pmel.noaa.gov/kuril20200325 (accessed 29.11.2020)

6. NOAA Center for Tsunami Research: Tsunami Forecasting. URL: https://nctr.pmel.noaa.gov/tsunami-forecast.html (accessed 7.12.2020)

7. Sea Level Station Monitoring Facility (Unesco. IOC). URL: http://www.ioc-

sealevelmonitoring.org/list.php?showall=a\&output=general\&order=location\&dir=asc (accessed 6.11.2020)

8. Nauchnyy Sovet po problemam tsunami pri otdelenii nauk o Zemle RAN: Rezultaty modelirovaniya tsunami $25.03 .2020 \mathrm{~s}$ pomoshchyu modeli NAMI-DANCE [Research Council on the tsunami problems of Earth sciences department RAS: Results of simulation of tsunami 25.03.2020 using the NAMI_DANCE model]. URL: http:/ ocean.phys.msu.ru/tsunamicouncil/news/2020/04/200325-namidance/ (accessed 6.11.2020)

9. Rossiyskaya sluzhba preduprezhdeniya o tsunami: Izmereniya urovnya morya [Russian tsunami warning service: Measuring sea level]. URL: http://rtws.ru/sea-level/ (accessed 6.11.2020)

10. [Sakhalin service for hydrometeorology and environmental monitoring: On the threat of a tsunami after the earthquake near the coast of the North Kuril region on March 25, 2020]. URL: http://sakhugms.ru/index.php/o-nas/strutura/tsentr-tsunami (accessed 6.11.2020) 